\title{
Leiomyosarcoma of the jaw: case series
}

\author{
Yong-Suk Choi ${ }^{1}$, Akram Abdo Almansoori ${ }^{1,2,3}$, Tae-Young Jung ${ }^{2,4}$, Jae-II Lee ${ }^{5}$, \\ Soung Min Kim ${ }^{1,3,6}$, Jong-Ho Lee ${ }^{1,2,3,6}$ \\ ${ }^{1}$ Department of Oral and Maxillofacial Surgery, Seoul National University Dental Hospital, Seoul, \\ ${ }^{2}$ Clinical Translational Research Center for Dental Science, Seoul National University Dental Hospital, Seoul, \\ ${ }^{3}$ Oral Cancer Center, Seoul National University Dental Hospital, Seoul, \\ ${ }^{4}$ Department of Oral and Maxillofacial Surgery, Inje University Busan Paik Hospital, Busan, \\ ${ }^{5}$ Department of Oral Pathology, Seoul National University Dental Hospital, Seoul, \\ ${ }^{6}$ Dental Research Institute, Seoul National University, Seoul, Korea
}

\begin{abstract}
J Korean Assoc Oral Maxillofac Surg 2020;46:275-281)
Objectives: Leiomyosarcoma is a malignant neoplasm that affects smooth muscle tissue and it is very rare in the field of oral and maxillofcial surgery. The purpose of this study was to obtain information on diagnosis of and treatment methods for leiomyosarcoma by retrospectively reviewing of the cases.

Patients and Methods: The study included nine patients who were diagnosed with leiomyosarcoma in the Department of Oral and Maxillofacial Surgery at Seoul National University Dental Hospital. The subjects were analyzed with respect to sex, age, clinical features, primary site of disease, treatment method, recurrence, and metastasis.

Results: Particular clinical features included pain, edema, mouth-opening limitations, dysesthesia, and enlarged lymph nodes. All cases except one were surgically treated, and recurrence was found in two cases. Four of nine patients were followed up without recurrence and one patient underwent additional surgery due to recurrence.

Conclusion: In our case series, notable symptoms included pain, edema, mouth-opening limitations, and dysesthesia; however, it was difficult to label these as specific symptoms of leiomyosarcoma. Considering the aggressive characteristics of the disease and poor prognosis, surgical treatment is necessary with careful consideration of postoperative radiotherapy and chemotherapy.
\end{abstract}

Key words: Leiomyosarcoma, Mouth neoplasm, Case series

[paper submitted 2019. 9. 13 / revised 2019. 11. 8 / accepted 2019. 11. 14]

\section{Introduction}

Leiomyosarcoma is a malignant neoplasm originating in smooth muscle that occurs most frequently in the uterus and gastrointestinal tract. Fernandez et al. ${ }^{1}$ reported that, although leiomyosarcoma accounts for approximately $7 \%$ of all soft tissue sarcomas, it is extremely rare in the field of oral and

\section{Jong-Ho Lee}

Department of Oral and Maxillofacial Surgery, Seoul National University Dental Hospital, 101 Daehak-ro, Jongno-gu, Seoul 03080, Korea

TEL: +82-2-2072-2630 FAX: +82-2-766-4948

E-mail:leejongh@snu.ac.kr

ORCID: https://orcid.org/0000-0002-8843-545X

(c) This is an open-access article distributed under the terms of the Creative Commons Attribution Non-Commercial License (http://creativecommons.org/ licenses/by-nc/4.0/), which permits unrestricted non-commercial use, distribution, and reproduction in any medium, provided the original work is properly cited.

Copyright (C) 2020 The Korean Association of Oral and Maxillofacial Surgeons. All rights reserved. maxillofacial surgery. According to the literature, only $0.64 \%$ of cases were reported to be in the oral area among 7,748 cases of smooth muscle malignant tumors ${ }^{2,3}$; this rarity is considered to be the result of low smooth muscle distribution in the oral cavity ${ }^{4-6}$. The most common clinical symptom of leiomyosarcoma is increased size of a painless mass, which is typically diagnosed when the patient visits the clinic after its recognition, as it does not show any distinguishing characteristics. It occurs across a wide range of ages and there is no significant difference in its incidence according to sex (11:9, male:female $)^{7}$. Leiomyosarcoma may occur in many areas in the oral cavity, but it is most common in the jawbone. Vilos et al. ${ }^{8}$ reported that $70 \%$ of cases of leiomyosarcoma occurring in the oral cavity involved the maxilla or mandible. Separately, Schenberg et al. ${ }^{6}$ and Izumi et al. ${ }^{9}$ presumed that the jawbone is the most commonly affected site of leiomyosarcoma in the oral cavity. 
As leiomyosarcoma itself is very rare, it is often misdiagnosed as other common benign lesions in the oral cavity prior to biopsy. In addition, prognosis is poor due to a high rate of local recurrence ${ }^{10,11}$, and a wide range of surgical resections are required for its treatment, sometimes with adjunctive chemotherapy or radiotherapy ${ }^{7}$. However, smooth musclederived tumors in the oral cavity are more likely to become malignant compared to those in the female genital tract, so it is crucial to check for any metastasis to other sites before surgery is performed ${ }^{3,12-14}$.

The purpose of the present paper was to obtain information on diagnosis of and treatment methods for leiomyosarcoma by retrospectively reviewing the clinical features, treatment methods, and outcomes of patients with histologically diagnosed leiomyosarcoma.

\section{Patients and Methods}

This study included nine patients who were diagnosed with leiomyosarcoma in the Department of Oral and Maxillofacial Surgery at Seoul National University Dental Hospital. The subjects were analyzed with respect to sex, age, clinical features, primary site of disease, treatment method, recurrence, and metastasis. This study was approved by the Institutional Review Board of Seoul National University Dental Hospital (IRB No. ERI19006), and the informed consent was waived.

\section{Results}

Nine leiomyosarcoma patients diagnosed between 2000 and 2018 are listed in Table 1. Their age ranged from 16 to
66 years and the disease occurred most frequently in the sixth decade of life (33\%). The ratio of males:females was 1:2 (three males and six females). There were three cases of leiomyosarcoma of the maxilla and four of the mandible, and one patient in whom both the maxilla and mandible were affected. In the last case, the lesion was found in the left infratemporal fossa. Particular clinical features of leiomyosarcoma included pain in seven cases, edema in six, limited mouth-opening in two, dysesthesia in three, and lymphadenopathy in three, with all nine patients showing bone invasion. Recurrence was observed in two cases, and metastasis was observed in three cases. In one unusual case, the patient was diagnosed with squamous cell carcinoma of the left lateral tongue in April 2013 and underwent partial glossectomy, selective neck dissection (level I, II, III), and postoperative radiotherapy. Then, in March 2017, the same patient visited the clinic due to an increase in mobility and pain in the anterior mandibular teeth. After tissue biopsy, the patient was diagnosed with a malignant mesenchymal tumor and received further surgery at Seoul National University Dental Hospital.(Fig. 1) The tumor was considered to be radiation-induced sarcoma, as it met all three of the following criteria: histological diagnosis, onset during radiotherapy, and a three- to five-year incubation pe$\operatorname{riod}^{15,16}$. Another notable case was a 23-year-old patient who visited the clinic in 2014. The patient was diagnosed with fibroma and underwent mass resection in March 2012. Subsequently, due to recurrence, the patient again received mass resection in May 2013 and June 2014. However, the disease recurred again in August 2017; it was initially diagnosed as a benign lesion but became malignant. A total of three recurrences were thus observed in this patient. At the last recur-

Table 1. Demographic and clinical data for nine cases of leiomyosarcoma in the maxillofacial area

\begin{tabular}{|c|c|c|c|c|c|c|}
\hline Case No. & Sex & Age $(y r)$ & Site & $\begin{array}{c}\text { Bone } \\
\text { invasion }\end{array}$ & $\mathrm{LN}$ & Clinical manifestation \\
\hline 1 & $\mathrm{M}$ & 62 & $\begin{array}{l}\text { Lt. Mx. and } \\
\text { inferior orbit }\end{array}$ & $\mathrm{O}$ & $\mathrm{X}$ & Lt. upper buccal swelling \& pain \\
\hline 2 & $\mathrm{~F}$ & 27 & Lt. TMJ ITF & $\mathrm{O}$ & $\mathrm{X}$ & $\begin{array}{l}\text { Lt. periauricular pain, mouth opening: } 1.5 \text { finger breadth, } \\
\text { Lt. lower lip sensation decreased }\end{array}$ \\
\hline 3 & $\mathrm{~F}$ & 61 & Lt. Mn. & $\mathrm{O}$ & $\mathrm{X}$ & Lt. Mn. cheek swelling \& paresthesia \\
\hline 4 & M & 66 & Ant. Mx. & $\mathrm{O}$ & $\begin{array}{c}\mathrm{O} \\
\text { (Rt. Lv Ib) }\end{array}$ & Gingival overgrowth \& redness on \#11, \#12, \#21; pain \\
\hline 5 & $\mathrm{~F}$ & 48 & Lt. Mn. & $\mathrm{O}$ & $\mathrm{X}$ & $\begin{array}{l}\text { Lt. buccal submandibular area mild swelling; pain }(+) \\
\text { Lt. lower paresthesia }\end{array}$ \\
\hline 6 & $\mathrm{~F}$ & 36 & Lt. Mx. & $\mathrm{O}$ & $\mathrm{X}$ & \#27 area gingival enlargement \& pain, ulcerative lesion \\
\hline 7 & $\mathrm{~F}$ & 23 & Lt. Mx., Mn. & $\mathrm{O}$ & $\mathrm{X}$ & Limited mouth opening, pain on Lt. ear to lip \\
\hline 8 & $\mathrm{M}$ & 16 & Lt. Mn. & $\mathrm{O}$ & $\mathrm{X}$ & Lt. Mn. pain, active bleeding, \#37 mob(+) \\
\hline 9 & $\mathrm{~F}$ & 55 & Rt. Mn. & $\mathrm{O}$ & $\mathrm{X}$ & $\begin{array}{l}\text { Gingival swelling around \#44, \#45 vestibular swelling } \\
\text { around \#42 to \#32,\#42 to \#44 mob(++ to +++) }\end{array}$ \\
\hline
\end{tabular}

(M: male, F: female, Lt.: left, Rt.: right, Mx.: maxilla, Mn.: mandible, TMJ: temporomandibular joint, ITF: infratemporal fossa, Ant.: anterior, LN: neck lymph node metastasis, Lv Ib: level Ib, mob: tooth mobility)

Yong-Suk Choi et al: Leiomyosarcoma of the jaw: case series. J Korean Assoc Oral Maxillofac Surg 2020 

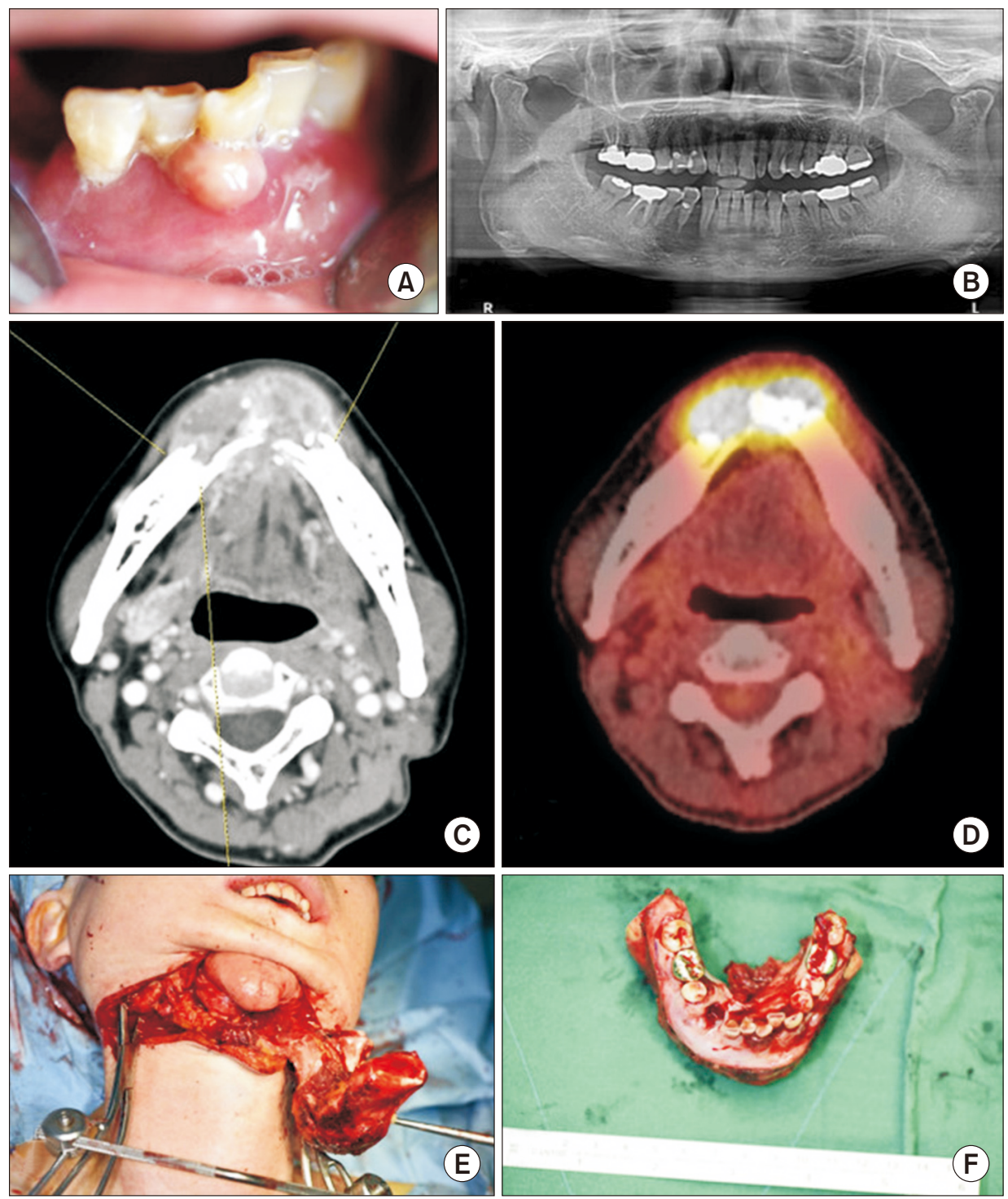

(D)
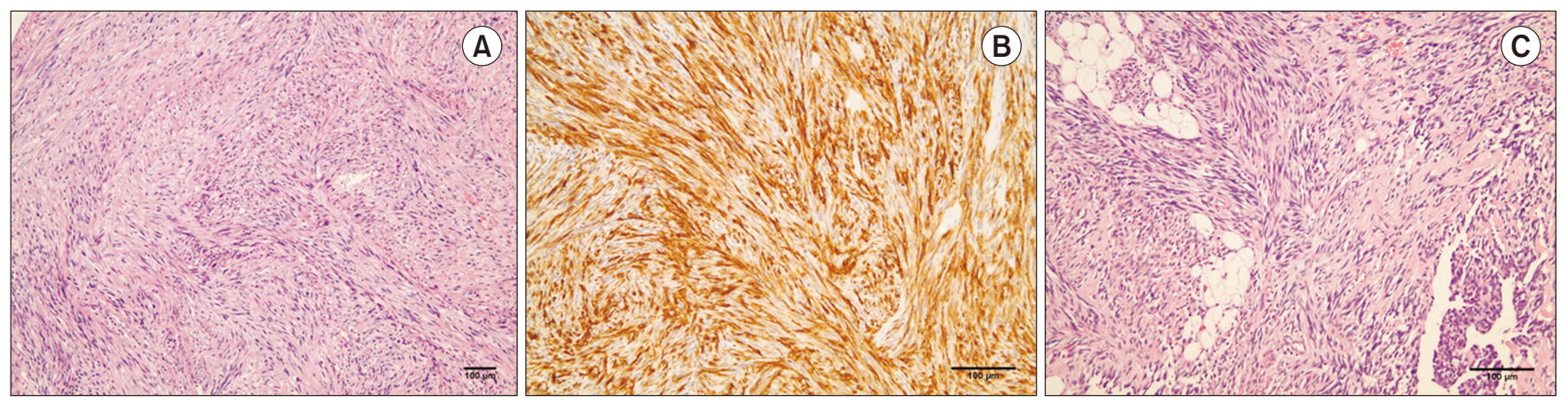

Fig. 2. A 23-year-old female patient. A. Microscopic image shows fascicles of spindle-shaped cells with blunt-ended cigar-shaped nuclei. B. Smooth muscle actin(+) positive cytoplasm in spindle-shaped tumor cells. C. Microscopic image of recurrent tumor shows similar-spindle shaped cells similar to panel A of Fig. 2 with increased cellularity and mitosis; some areas of tumor show rounded cells with eosinophilic cytoplasm. H\&E and immunohistochemical staining, A: $\times 100$; B and C: $\times 200$.

Yong-Suk Choi et al: Leiomyosarcoma of the jaw: case series. J Korean Assoc Oral Maxillofac Surg 2020 
Table 2. Treatment and follow-up data for nine cases of leiomyosarcoma

\begin{tabular}{|c|c|c|c|c|c|c|c|c|}
\hline Case No. & Main therapy & $\begin{array}{l}\text { Adjunctive } \\
\text { therapy }\end{array}$ & $\begin{array}{l}\text { Resection } \\
\text { margin }\end{array}$ & Recur & Meta & Reconstruction & $\begin{array}{l}\mathrm{F} / \mathrm{U} \\
(\mathrm{mo})\end{array}$ & Status \\
\hline 1 & $\begin{array}{l}\text { No treatment, referral to } \\
\text { hemato-oncology }\end{array}$ & - & - & INA & Liver & - & INA & INA \\
\hline 2 & $\begin{array}{l}\text { Partial mandibulectomy, } \\
\text { Lt. SOHND }\end{array}$ & $\mathrm{RT}+\mathrm{CHT}$ & Clear & $\mathrm{O}$ & Lung & $\begin{array}{l}\text { Serratus anterior } \\
\text { free flap }\end{array}$ & 8 & INA \\
\hline 3 & $\begin{array}{l}\text { Partial mandibulectomy, } \\
\text { Lt. SOHND }\end{array}$ & - & Clear & INA & $\mathrm{X}$ & $\begin{array}{l}\text { LD free flap \& } \\
\text { R-plate }\end{array}$ & 72 & INA \\
\hline 4 & $\begin{array}{l}\text { Partial maxillectomy on Ant. } \\
\text { Mx., FTSG; } \\
\text { 2nd operation: SND }\end{array}$ & - & Clear & INA & $\mathrm{X}$ & - & INA & INA \\
\hline 5 & $\begin{array}{l}\text { Partial mandibulectomy, } \\
\text { Lt. SND }\end{array}$ & - & Clear & $\mathrm{X}$ & $\mathrm{X}$ & Fibular free flap & 96 & Alive \\
\hline 6 & $\begin{array}{l}\text { Subtotal maxillectomy (Lt.), } \\
\text { Lt. SND, STSG }\end{array}$ & - & Clear & $\mathrm{X}$ & $\mathrm{X}$ & $\begin{array}{l}\text { Radial forearm } \\
\text { free flap }\end{array}$ & 53 & Alive \\
\hline 7 & $\begin{array}{l}\text { Partial maxillectomy \& } \\
\text { partial mandibulectomy, } \\
\text { 2nd operation: Lt. buccal } \\
\text { cheek mass resection }\end{array}$ & - & Clear & $\mathrm{O}$ & $\mathrm{X}$ & $\begin{array}{l}\text { LD free flap \& } \\
\text { R-plate }\end{array}$ & 54 & Alive \\
\hline 8 & $\begin{array}{l}\text { Marginal mandibulectomy } \\
\text { 2nd operation: open biopsy } \\
\text { with frozen biopsy }\end{array}$ & - & Clear & $\mathrm{X}$ & $\mathrm{X}$ & - & 34 & Alive \\
\hline 9 & $\begin{array}{l}\text { Partial mandibulectomy, } \\
\text { tracheostomy }\end{array}$ & - & Clear & $\mathrm{X}$ & $\mathrm{X}$ & Fibular free flap & 16 & Alive \\
\hline
\end{tabular}

(Lt.: left, SOHND: supraomohyoid neck dissection, Ant.: anterior, Mx.: maxilla, FTSG: full-thickness skin graft, SND: selective neck dissection, STSG: split-thickness skin graft, RT: radiotherapy, CHT: chemotherapy, INA: information not available, Meta: metastases in other sites [except neck lymph nodes], LD: latissimus dorsi, F/U: follow up)

Yong-Suk Choi et al: Leiomyosarcoma of the jaw: case series. J Korean Assoc Oral Maxillofac Surg 2020

rence, the histologic findings were different from the typical pattern, and some areas of tumor showed rounded cells with eosinophilic cytoplasm.(Fig. 2)

During the follow-up period, one patient had large mass involving the right inferior orbit and was transferred to the Department of Hemato-Oncology, while all other patients received surgical treatment.(Table 2) Partial mandibulectomy was performed for all mandibular lesions except in one case where marginal mandibulectomy was performed due to the patient's young age. There was also a case in which the patient received implant treatment, as the progress was good after reconstruction.(Fig. 3) Two patients underwent reconstruction using a latissimus dorsi free flap and reconstruction plate, two patients had a fibular free flap, one patient each had a radial forearm free flap, full-thickness skin graft, and serratus anterior free flap. Partial mandibulectomy was performed in only one case. In addition, supraomohyoid neck dissection was performed in a 27 -year-old female patient in 2003 and a 61-year-old female patient in 2008, while selective neck dissection was performed in a 48-year-old female patient in 2010 and 36-year-old female patient in 2014.

The follow-up period ranged from eight to 96 months in length, and four patients who visited between 2000 and 2009 did not return to the clinic during their follow-up periods.
Conversely, four patients are still undergoing follow-up without any observed recurrence. Recurrence was, however, noted in two patients after surgery at Seoul National University Dental Hospital; one patient was moved to another hospital due to lung metastasis, and the other patient received additional mass resection.

\section{Discussion}

Age of patient was varied from 16 to 66 years old (mean age, 43.8 years). In our patient cohort, leiomyosarcoma occurred most frequently in the seventh decade of life, which corresponds to other studies also showing that it occurs most frequently in the sixth or seventh decades of life ${ }^{3,5,13}$. Vilos et al. ${ }^{8}$ and Schenberg et al. ${ }^{6}$ reported that the most frequent site of leiomyosarcoma was in the jawbone, and eight out of nine cases in these studies were in the maxillary and mandibular jawbone. There was also one unusual case found in the buccal area of the temporomandibular joint. However, $\mathrm{Ko}^{17}$ reported that the most common location for primary oral leiomyosarcoma seems to be soft tissue, and not the jawbones, as frequently reported. Further research is needed to clarify this point.

According to the English literature, a painless mass is a 

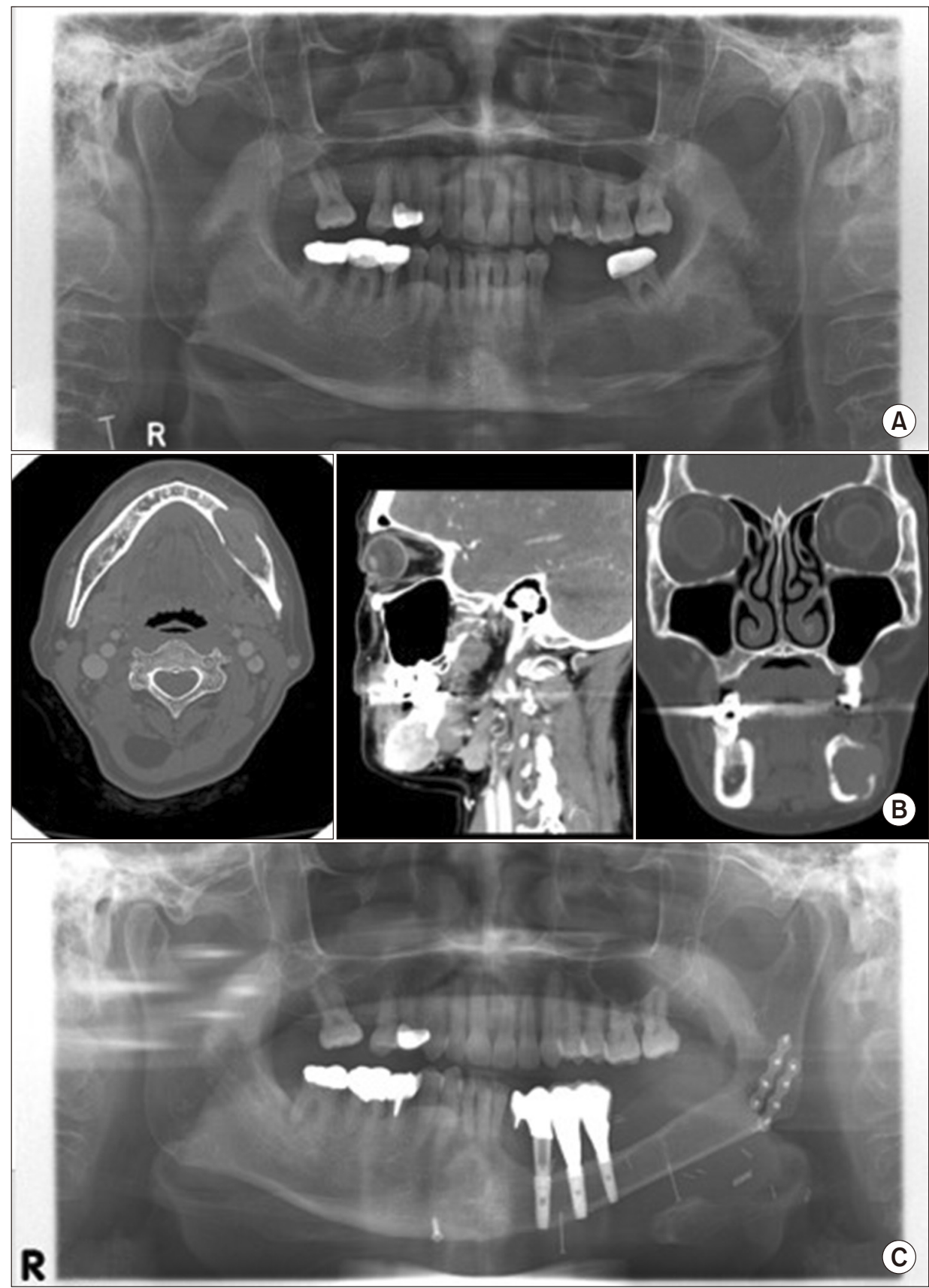

Fig. 3. A 48-year-old female patient. A. Preoperative panoramic image. Unclear radiography was observed at the left mandibular site; the border of the lesion was from \#34 posterior to the left mandibular site. The alveolar crest was intact but cortical bone loss was observed at the lower mandible. B. Enhanced computerized tomographic image; a large, enhancing lesion was observed at \#34 to \#36, filling the marrow of the left mandible, partially perforating the cortical bone and swelling outwards, making buccal contact at the lower buccinator muscle and pushing the platysma muscle outwards. There is also lateral contact at the mylohyoid muscle and the anterior belly of the digastric muscle as well as anterior contact at the edge of sublingual gland. The mandibular canal was within the lesion, surrounded by the enhancing lesion. C. Postoperative panoramic image. Two years postoperatively, dental implants and prostheses are attached at the fibular region and there is no evidence of recurrence.

Yong-Suk Choi et al: Leiomyosarcoma of the jaw: case series. J Korean Assoc Oral Maxillofac Surg 2020 general symptom of leiomyosarcoma ${ }^{18-20}$ and there are no other specific symptoms. However, the symptoms of the patients who visited the clinic in this study included pain in seven cases, edema in six, limited mouth-opening in two, dysesthesia in three, and lymphadenopathy in three, and all of these patients were ultimately diagnosed with leiomyosarcoma after biopsy. Treatment for any disease considered clinically or radiologically benign must be confirmed with biopsy. This is critical especially with leiomyosarcoma due to its nonspecific symptoms, confusion with other diseases such as osteoradionecrosis, and rarity in the oral cavity.
Many previous studies have reported that the optimal treatment of leiomyosarcoma is surgical management ${ }^{7,19,21-25}$. Extensive surgical resections were performed for all present cases except in one case of metastasis. However, considering the difficulty of approach due to the unusual anatomical locations such as the infratemporal fossa, maxillary sinus, pterygoid plate, and mandibular condyle as well as the proximity of critical anatomic structures and need for reconstruction, it may be difficult to obtain a negative resection margin, and recurrence due to remaining tumor could lead to poor prognosis ${ }^{8,9,26}$. Yadav et al. ${ }^{27}$ and Suárez-Alén et al. ${ }^{28}$ emphasized 
that early diagnosis and treatment of leiomyosarcoma are important for good prognosis.

Postoperative radiotherapy and chemotherapy have been discussed previously. Akcam et al. ${ }^{21}$ underlined that postoperative radiotherapy reduces the possibility of leiomyosarcoma recurrence. Schütz et al. ${ }^{29}$ reported that adjuvant radiation and chemotherapy also may have a beneficial effect in decreasing or delaying the recurrence rate, improving survival time, and sometimes allowing the possibility of less radical resection. Other literature has suggested that the effects of chemotherapy are still ambiguous and it should be performed only in patients who cannot receive surgical treatment ${ }^{6,13}$. However, Mitsudo et al. ${ }^{30}$ noted that chemotherapy is effective and Yan et al. ${ }^{7}$ reported that patients receiving postoperative radiotherapy or chemotherapy showed better results, although there was no statistically significant difference observed. Among the nine patients in this study, one received chemotherapy and radiotherapy, but did not present for follow-up. One patient in this study previously received surgery due to squamous cell carcinoma, but developed leiomyosarcoma after the postoperative radiotherapy treatment for this prior malignancy. Therefore, postoperative radiotherapy must be considered carefully. Further research is needed on the subject of radiotherapy and chemotherapy at the management of leiomyosarcoma.

\section{Conclusion}

Leiomyosarcoma is a very rare disease in the oral cavity that shows poor prognosis due to its high rate of recurrence. In this case series, notable symptoms included pain, edema, mouth-opening limitations, and dysesthesia; however, it is difficult to label these as specific symptoms of leiomyosarcoma. Considering the aggressive characteristics of the disease, surgical treatment is necessary. However, postoperative radiotherapy and chemotherapy must also be carefully considered. Moreover, patients should be monitored for any sign of recurrence during regular, detailed follow-up visits. In case of recurrence, surgical intervention should be implemented to contribute to a better potential for survival in the patient. In addition, since the prognosis of oral leiomyosarcoma is poor, periodic oral examination and early detection and treatment of this cancer are important.

\section{ORCID}

Yong-Suk Choi, https://orcid.org/0000-0001-8618-4100
Akram Abdo Almansoori, https://orcid.org/0000-00017134-9195

Tae-Young Jung, https://orcid.org/0000-0001-7131-358X

Jae-Il Lee, https://orcid.org/0000-0002-1066-0980

Soung Min Kim, https://orcid.org/0000-0002-6916-0489

Jong-Ho Lee, https://orcid.org/0000-0002-8843-545X

\section{Author's Contributions}

Y.S.K. participated in data collection and wrote the manuscript. A.A.A. and T.Y.J. participated in the study design and performed the English revision. J.I.L., S.M.K., and J.H.L. participated in the surgery, pathologic review and drafting the manuscript. All authors read and approved the final manuscript.

\section{Acknowledgements}

This paper was supported by a grant from the Korea Health Technology R\&D Project through the Korea Health Industry Development Institute (KHIDI), funded by the Ministry of Health \& Welfare, Republic of Korea (grant No. HI15C1535). The authors are very grateful to the following people who provided case material and clinical details for the cases reported here: Han Bin Lee, DDS, Kyung Won Ju, MinSun Lee, RDH, Han Wool Choung, DDS, PhD, and Bong-Ju Kim, PhD.

\section{Ethics Approval and Consent to Participate}

This study was approved by the Institutional Review Board of Seoul National University Dental Hospital (IRB No. ERI19006), and the informed consent was waived.

\section{Conflict of Interest}

No potential conflict of interest relevant to this article was reported.

\section{References}

1. Fernandez Sanroman J, Alonso del Hoyo JR, Diaz FJ, Gil-Diez JL, Monje F, Naval L, et al. Sarcomas of the head and neck. Br J Oral Maxillofac Surg 1992;30:115-8. https://doi.org/10.1016/02664356(92)90081-s

2. Farman AG. Benign smooth muscle tumours. S Afr Med J 1975;49:1333-40.

3. Wertheimer-Hatch L, Hatch GF 3rd, Hatch BS KF, Davis GB, 
Blanchard DK, Foster RS Jr, et al. Tumors of the oral cavity and pharynx. World J Surg 2000;24:395-400. https://doi.org/10.1007/ s002689910064

4. Carter LC, Aguirre A, Boyd B, DeLacure MD. Primary leiomyosarcoma of the mandible in a 7-year-old girl: report of a case and review of the literature. Oral Surg Oral Med Oral Pathol Oral Radiol Endod 1999;87:477-84. https://doi.org/10.1016/s10792104(99)70248-9

5. Lo Muzio L, Favia G, Mignogna MD, Piattelli A, Maiorano E. Primary intraoral leiomyosarcoma of the tongue: an immunohistochemical study and review of the literature. Oral Oncol 2000;36:519-24. https://doi.org/10.1016/s1368-8375(00)00044-0

6. Schenberg ME, Slootweg PJ, Koole R. Leiomyosarcomas of the oral cavity. Report of four cases and review of the literature. J Craniomaxillofac Surg 1993;21:342-7. https://doi.org/10.1016/s10105182(05)80495-0

7. Yan B, Li Y, Pan J, Xia H, Li LJ. Primary oral leiomyosarcoma: a retrospective clinical analysis of 20 cases. Oral Dis 2010;16:198203. https://doi.org/10.1111/j.1601-0825.2009.01635.x

8. Vilos GA, Rapidis AD, Lagogiannis GD, Apostolidis C. Leiomyosarcomas of the oral tissues: clinicopathologic analysis of 50 cases. J Oral Maxillofac Surg 2005;63:1461-77. https://doi.org/10.1016/ j.joms.2005.06.018

9. Izumi K, Maeda T, Cheng J, Saku T. Primary leiomyosarcoma of the maxilla with regional lymph node metastasis. Report of a case and review of the literature. Oral Surg Oral Med Oral Pathol Oral Radiol Endod 1995;80:310-9. https://doi.org/10.1016/s10792104(05)80389-0

10. Nikitakis NG, Lopes MA, Bailey JS, Blanchaert RH Jr, Ord RA, Sauk JJ. Oral leiomyosarcoma: review of the literature and report of two cases with assessment of the prognostic and diagnostic significance of immunohistochemical and molecular markers. Oral Oncol 2002;38:201-8. https://doi.org/10.1016/s13688375(01)00047-1

11. Sumida T, Hamakawa H, Otsuka K, Tanioka H. Leiomyosarcoma of the maxillary sinus with cervical lymph node metastasis. J Oral Maxillofac Surg 2001;59:568-71. https://doi.org/10.1053/ joms.2001.22691

12. Allen CM, Neville B, Damm DD, Marsh W. Leiomyosarcoma metastatic to the oral region. Report of three cases. Oral Surg Oral Med Oral Pathol 1993;76:752-6. https://doi.org/10.1016/00304220(93)90047-8

13. Dry SM, Jorgensen JL, Fletcher CD. Leiomyosarcomas of the oral cavity: an unusual topographic subset easily mistaken for nonmesenchymal tumours. Histopathology 2000;36:210-20. https://doi. org/10.1046/j.1365-2559.2000.00814.x

14. Kim SM, Myoung H, Choung PH, Kim MJ, Lee SK, Lee JH. Metastatic leiomyosarcoma in the oral cavity: case report with protein expression profiles. J Craniomaxillofac Surg 2009;37:454-60. https://doi.org/10.1016/j.jcms.2009.06.010

15. Arlen M, Higinbotham NL, Huvos AG, Marcove RC, Miller T, Shah IC. Radiation-induced sarcoma of bone. Cancer 1971;28:1087-99. https://doi.org/10.1002/10970142(1971)28:5<1087::aid-cncr2820280502>3.0.co;2-f

16. Cahan WG, Woodard HQ, Higinbotham NL, Stewart FW, Coley BL. Sarcoma arising in irradiated bone: report of eleven cases. 1948. Cancer 1998;82:8-34. https://doi.org/10.1002/(sici)10970142(19980101)82:1<8::aid-cncr3>3.0.co;2-w

17. Ko E. Primary oral leiomyosarcoma: a systematic review and update. J Oral Pathol Med 2019;48:780-7. https://doi.org/10.1111/ jop. 12858

18. Amarapala H, Tilakaratne WM. Leiomyosarcoma of the oral cavity: report of seven cases and review of literature. Oral Oncol Extra 2006;42:14-7. https://doi.org/10.1016/j.ooe.2005.08.001

19. Ethunandan M, Stokes C, Higgins B, Spedding A, Way C, Brennan P. Primary oral leiomyosarcoma: a clinico-pathologic study and analysis of prognostic factors. Int J Oral Maxillofac Surg 2007;36:409-16. https://doi.org/10.1016/j.ijom.2006.12.015

20. Montgomery E, Goldblum JR, Fisher C. Leiomyosarcoma of the head and neck: a clinicopathological study. Histopathology 2002;40:518-25. https://doi.org/10.1046/j.1365-2559.2002.01412.x

21. Akcam T, Oysul K, Birkent H, Gerek M, Yetiser S. Leiomyosarcoma of the head and neck: report of two cases and review of the literature. Auris Nasus Larynx 2005;32:209-12. https://doi. org/10.1016/j.anl.2005.01.012

22. Crossman T, Ward P, Herold J. Leiomyosarcoma of the tongue: a case report. Br J Oral Maxillofac Surg 2008;46:e69-70. https://doi. org/10.1016/j.bjoms.2008.03.008

23. Misra A, Mistry N, Grimer R, Peart F. The management of soft tissue sarcoma. J Plast Reconstr Aesthet Surg 2009;62:161-74. https:// doi.org/10.1016/j.bjps.2008.08.018

24. Ries Centeno C, Nadini F, Adam R, Godoy H, Reichart PA. Primary leiomyosarcoma of the mandible. Oral Oncol Extra 2006;42:405. https://doi.org/10.1016/j.ooe.2005.08.008

25. Rodini CO, Pontes FS, Pontes HA, Santos PS, Magalhães MG, Pinto DS Jr. Oral leiomyosarcomas: report of two cases with immunohistochemical profile. Oral Surg Oral Med Oral Pathol Oral Radiol Endod 2007;104:e50-5. https://doi.org/10.1016/ j.tripleo.2007.05.005

26. Rapidis AD, Gakiopoulou H, Stavrianos SD, Vilos GA, Faratzis G, Douzinas EE, et al. Sarcomas of the head and neck. Results from the treatment of 25 patients. Eur J Surg Oncol 2005;31:177-82. https://doi.org/10.1016/j.ejso.2004.09.020

27. Yadav J, Bakshi J, Chouhan M, Modi R. Head and neck leiomyosarcoma. Indian J Otolaryngol Head Neck Surg 2013;65(Suppl 1):1-5. https://doi.org/10.1007/s12070-011-0305-8

28. Suárez-Alén F, Otero-Rey E, Peñamaría-Mallón M, García-García A, Blanco-Carrión A. Oral leiomyosarcoma: the importance of early diagnosis. Gerodontology 2015;32:314-7. https://doi. org $/ 10.1111 /$ ger. 12126

29. Schütz A, Smeets R, Driemel O, Hakim SG, Kosmehl H, Hanken H, et al. Primary and secondary leiomyosarcoma of the oral and perioral region--clinicopathological and immunohistochemical analysis of a rare entity with a review of the literature. J Oral Maxillofac Surg 2013;71:1132-42. https://doi.org/10.1016/j.joms.2012.12.011

30. Mitsudo K, Tohnai I, Fujimoto Y, Sawaki Y, Sugimura T, Nishiguchi $\mathrm{H}$, et al. Leiomyosarcoma of the maxilla: effective chemotherapy with docetaxel (DOC) and cisplatin (CDDP) using superselective intra-arterial infusion via superficial temporal artery. Oral Oncol Extra 2006;42:258-62. https://doi.org/10.1016/ j.ooe.2006.05.001

How to cite this article: Choi YS, Almansoori AA, Jung TY, Lee JI, Kim SM, Lee JH. Leiomyosarcoma of the jaw: case series. J Korean Assoc Oral Maxillofac Surg 2020;46:275-281. https://doi org/10.5125/jkaoms.2020.46.4.275 